American Journal of Economics and Business Administration 2 (1): 45-55, 2010

ISSN 1945-5488

(C) 2010 Science Publications

\title{
Explaining Local Growth-Management Policies: The Role of Public Goods
}

\author{
${ }^{1}$ Donna Driscoll, ${ }^{2}$ Dennis Halcoussis and ${ }^{2}$ Anton D. Lowenberg \\ ${ }^{1}$ Department of Accounting and Information Systems, \\ ${ }^{2}$ Department of Economics, \\ California State University, Northridge, 18111 Nordhoff Street, Northridge, CA 91330
}

\begin{abstract}
Problem statement: Local jurisdictions such as cities and counties enact a wide variety of growth-management regulations, such as zoning ordinances and growth-promoting incentives. Approach: Use a theory of local public goods to identify the conditions under which jurisdictions are most likely to implement growth-management regulations. Predictions of the theory regarding variation in pro-growth measures across jurisdictions were tested using data on California cities. Results: Communities whose current expenditures on public amenities are high typically have more extensive growth-promoting policies, while communities that already have substantial public infrastructure in place are less likely to implement effective pro-growth measures. Conclusion: These findings suggest that changes in stocks and flows of public goods can be used as predictors of the incidence of growth controls.
\end{abstract}

Key words: Local public goods, local expenditure, public infrastructure, land-use regulations

\section{INTRODUCTION}

As California's population density has increased over the past three decades, local jurisdictions have enacted an increasing number of regulations and ordinances designed to manage or control growth. In a landmark study conducted in 1992 that covered 55 of California's 57 counties and 410 of the state's 466 cities, it was found that there were over 1,500 local growth-control measures in effect, $60 \%$ more than in 1988 (Glickfeld et al., 1996). Glickfeld et al. (1996) identified eighteen different types of growth-control measures, ranging from zoning restrictions on residential and commercial development to construction moratoria and development-impact fees. Approximately $85 \%$ of California jurisdictions had enacted at least one growth-control measure, with a great deal of variation among jurisdictions in both the number and the types of measures. Local growth controls are an issue of concern for California because rapid expansion of the state's population threatens to outstrip the supply of housing, resulting in further increases in real estate prices and shortages of affordable housing particularly for lowand moderate-income groups (Levine, 1999).

The purpose of the present study is to identify the factors that have driven this proliferation of local growth-management regulations. We use a theory of local public goods to explain the reasons that jurisdictions adopt such measures and to suggest the circumstances that are most likely to lead to these policies being implemented. The local public good supply problem has traditionally been analyzed as analogous to that of a club good (Buchanan, 1965). Like a club, the provider of a local public good must decide on the optimal quantity of the good to supply as well as the optimal number of users to share in its consumption and to help pay for it through dues, fees or taxes. The optimal number of users is the number that maximizes the per-user net benefit obtained from consuming the good in question. If the number of users is too low, each person's contribution to the cost of providing the good would be high, reducing the net benefit to the user. On the other hand, if the number of users is too great, congestion will occur. These two countervailing effects need to be balanced at the margin to determine the optimal quantity of the public good and the optimal number of users. Moreover, there also needs to be some mechanism to regulate entry in order to keep the sharing community at its optimal size.

A jurisdiction can regulate access to its public amenities by regulating the size of its population. There are many mechanisms available to communities to achieve this end (Halcoussis and Lowenberg, 1998), but the most obvious are growth-control measures such as zoning ordinances, development-impact fees, etc. As Fennell (2004) points out, by excluding certain

Corresponding Author: Dennis Halcoussis, Department of Economics, California State University, Northridge, 18111 Nordhoff Street, Northridge, CA 91330-8374 Tel: 818-677-4566 Fax: 818-677-60791 
disfavored land uses, municipal zoning regulations also effectively exclude their users, whose mobility is thereby constrained. We develop an empirical model that identifies those factors that are most important in determining the number or effectiveness of growthmanagement measures enacted by local jurisdictions. For data reasons, we focus on growth-promoting policies rather than directly on growth restrictions. The local public goods theory predicts that communities whose current expenditures on public amenities are high will need to attract new residents (taxpayers) in order to help finance these expenditures, so that progrowth regulations in such communities would be expected to be more extensive. On the other hand, communities that already have substantial public infrastructure in place have a strong incentive to limit congestion of those facilities. Such communities are likely to be characterized by fewer, or less effective, pro-growth measures. These and other related hypotheses are tested with survey data from California cities. Our results confirm the predictions of the local public goods theory.

Much of the existing literature has focused on the effects of growth-control measures on housing construction or on residence patterns, e.g., Levine (1999). Byun et al. (2005) identify spillover effects of growth restrictions in the form of spatial shifting of households to neighboring localities. Glickfeld and Levine (1992) point out that jurisdictions lying adjacent to highly congested regions might be more likely to enact growth-control measures even if they themselves are not congested. Garcia (2004) notes the impact of urban growth controls on land prices and fiscal revenues. Others have viewed growth controls as instruments of strategic competition among jurisdictions, e.g., Brueckner (1998). With the exception of Richer (1995), who examines the determinants of voting on local growth-control ballot initiatives, very little has been done by way of explaining what causes growth-management measures to be adopted in the first place. The present study is one of the first to empirically implement a theory of local public goods in order to account for variation in growth policies across jurisdictions.

Below we describe a theoretical model of local public goods allocation and the rationale for jurisdictional entry regulations. We then discuss the data used in the empirical analysis and we present the results of multiple regression models designed to test the predictions of the theory.

A local public goods theory of community size and composition: We use a model of optimal migration of mobile factors between regions and optimal jurisdiction size. This analysis is in the tradition of Buchanan (1965); Buchanan and Wagner (1970); Buchanan and Goetz (1972) and Flatters et al. (1974), with further explication of this approach provided by Atkinson and Stiglitz (1980) and Starrett (1988). According to this literature, the only allocation of mobile factors between regions that is sustainable in competitive equilibrium is one that equalizes per-person utility levels across regions.

Each region or community can be viewed as a club in which members jointly consume some local public good. Consumption of this good is at least partially rivalrous, which implies that the optimal membership size for each club is less than inclusive of the entire population (Buchanan, 1965). Rivalry can exist in a number of different forms. Pure congestion rivalry, as in Buchanan's club model, occurs when the number of members of the club enters directly into each member's utility function. Beyond some critical membership size, the representative individual's utility is assumed to decline as additional members join the club. In essence, crowding causes the individual's utility to fall because the quality of the public good provided to the individual is reduced when the sharing community becomes too large. Another type of rivalry in public good consumption is "service rivalry," which is used in Tiebout's model of local public goods (Tiebout, 1956). For a fixed level of quality of the public good, the addition of new members lowers each person's share of the operating cost, as the total cost is divided among a larger number of taxpayers, but, at the same time, service or maintenance charges increase with the addition of new members. At first, the former effect dominates, so that total per-person cost falls. However, at some point the rising service charges become dominant, so that total per-person cost starts rising. The total per-person cost function therefore has a U-shape (Starrett, 1988).

Congestion also can be modeled in terms of spatial rivalry. Here it is assumed that, in order to consume the public good, it is necessary to occupy space in close proximity to its location. Spatial crowding can be characterized by a Ricardian site rent model, in which the addition of mobile factors of production to a fixed amount of land results in diminishing returns and increasing rent. At first it is desirable to add more of the mobile factors, because the growing rent can be used to help pay for the public good, and therefore enable each factor owner to keep a larger share of his income for private good consumption. But this beneficial effect eventually is outweighed by declining marginal products of the mobile factors. The optimal population of the region, for any given quantity of the public good, 
is that which maximizes per-person after-tax consumption of private goods. Spatial crowding also can be modeled in terms of rising transport costs (Starrett, 1988).

The model used here is based on the existence of both pure congestion rivalry and spatial rivalry. We assume that there are two mobile factors of production, labor and capital. We also assume, following Berglas (1976) and McGuire (1991), that capital owners and workers reside together in mixed communities due to the fact that they work together in the production of private goods. Each individual factor owner works in the same community in which he lives, i.e., consumes local public goods. The model differs in this respect from an alternative approach, exemplified by Oates (1977) and Schwab and Oates (1991), in which individuals can live and work at different locations because the fundamental rationale for mixed communities is unrelated to the production of private goods. In Oates (1977) and Schwab and Oates (1991), the main reason for heterogeneity in community composition stems from complementarities between individuals, not in production of private goods, but in production of local public goods. Each community seeks an optimal mix of individuals with different personal characteristics, like education and family background, which are assumed to affect the per-person cost of producing such local public goods as police protection. Fennell (2001) describes the impacts of individual community members' participatory behavior on the quality of public goods. Like Berglas (1976) and McGuire (1991), however, we assume a coincidence of place of work and place of local public good consumption. Without this restriction, all factor owners would simply choose to live in the community with the largest endowment of land, because this community would charge the lowest tax-price for public goods and provide the largest public good consumption (Flatters et al., 1974). To preclude this result, it might be supposed that positive transport costs, or commuting costs, constrain the ability of factor owners to congregate in a single residential community and work somewhere else.

To derive the optimal allocation of the local public good and the optimal membership size for any given region we will assume that output, $y$, produced in that region is an increasing, concave function of the number of workers, 1 , and the number of capital owners, $\mathrm{k}$. That is:

$\mathrm{y}=\mathrm{f}(\mathrm{l}, \mathrm{k}), \mathrm{f}_{\mathrm{l}}>0, \mathrm{f}_{\mathrm{k}}>0, \mathrm{f}_{\mathrm{ll}}<0, \mathrm{f}_{\mathrm{kk}}<0$

Both 1 and $\mathrm{k}$ are essential to produce a positive output, i.e., $\mathrm{f}(0, \mathrm{k})=\mathrm{f}(1,0)=0$ (Atkinson and Stiglitz, 1980). Output can be used either for private consumption, or for a public good. Each individual, i, has a utility function of the form:

$\mathrm{U}^{\mathrm{i}}=\mathrm{U}^{\mathrm{i}}\left(\mathrm{x}^{\mathrm{i}}, \mathrm{g}, \mathrm{n}\right), \mathrm{U}_{\mathrm{x}}^{\mathrm{i}}>0, \mathrm{U}_{\mathrm{g}}^{\mathrm{i}}>0, \mathrm{U}_{\mathrm{n}}^{\mathrm{i}}<0$,

$\mathrm{i}=1, \mathrm{k}$

$\mathrm{n}=1+\mathrm{k}$,

Where:

$\mathrm{x}^{\mathrm{i}}=$ The quantity of the private good, $\mathrm{x}$, consumed by individual $\mathrm{i}$

$\mathrm{g}=$ The quantity of the local public good supplied

Units of $\mathrm{x}$ and $\mathrm{g}$ are defined so that each price equals one. The utility function in (2) is assumed to be quasi-concave. A further assumption is that each community or region is a "utility-taker," which means that it can attract as many individuals of type 1 or $\mathrm{k}$ as it desires by offering them a level of utility at least as great as that which they could attain in an alternative community. Utility-taking behavior of the community, which is analogous to price-taking behavior of the firm, ensures that in a competitive multi-region equilibrium, all individuals of a given type must have the same utility in all communities in which they live, and must perceive themselves to obtain a lower utility in any other community (Atkinson and Stiglitz, 1980). This presupposes the existence of a competitive equilibrium. Problems of existence of equilibrium are discussed below. Assuming that all communities contain people of both types, let $\mathrm{U}^{\mathrm{i}^{*}}$ be the level of utility obtained by individuals of type $i$ in all communities.

To derive the Pareto efficient allocation of local public goods, consider the following maximization problem for a single community "(the approach used here is similar to Atkinson and Stiglitz (1980), except that they do not model pure congestion rivalry)":

Maximize $\quad \mathrm{U}^{\mathrm{k}}\left(\mathrm{x}^{\mathrm{k}}, \mathrm{g}, \mathrm{n}\right)$

$\left\{\mathrm{x}^{\mathrm{l}}, \mathrm{x}^{\mathrm{k}}, \mathrm{l}, \mathrm{k}, \mathrm{g}\right\}$

subject to: $\mathrm{U}^{\mathrm{l}}\left(\mathrm{x}^{1}, \mathrm{~g}, \mathrm{n}\right) \geq \mathrm{U}^{\mathrm{N}^{*}}$,

$g+1 x^{1}+k x^{k}=f(1, k)$,

and

$\mathrm{n}=1+\mathrm{k}$

Forming the Lagrangean:

$\mathrm{L}=\mathrm{U}^{\mathrm{k}}\left(\mathrm{x}^{\mathrm{k}}, \mathrm{g}, \mathrm{l}+\mathrm{k}\right)+\lambda_{1} \mathrm{U}^{\mathrm{l}}\left(\mathrm{x}^{1}, \mathrm{~g}, \mathrm{l}+\mathrm{k}\right)+\lambda_{2}\left[\mathrm{f}(\mathrm{l}, \mathrm{k})-\mathrm{g}-1 \mathrm{x}^{1}-\mathrm{kx} \mathrm{k}^{\mathrm{k}}\right]$

yields the following first order conditions:

$\lambda_{1} \mathrm{U}^{\mathrm{l}}{ }_{\mathrm{x}}=\lambda_{2} \mathrm{l}$ and $\mathrm{U}^{\mathrm{k}}{ }_{\mathrm{x}}=\lambda_{2} \mathrm{k}$ 
$\lambda_{2}\left(f_{1}-X^{1}\right)=\lambda_{2}\left(f_{k}-x^{k}\right)=-\left(U^{k}{ }_{n}+\lambda_{1} U^{1}\right)$

$\mathrm{U}_{\mathrm{g}}^{\mathrm{k}}+\lambda_{1} \mathrm{U}_{\mathrm{g}}^{\mathrm{l}}=\lambda_{2}$

Eliminating the $\lambda$ s from (7), we obtain:

$1\left(\mathrm{U}_{\mathrm{g}}^{\mathrm{l}} / \mathrm{U}_{\mathrm{x}}^{\mathrm{l}}\right)+\mathrm{k}\left(\mathrm{U}_{\mathrm{g}}^{\mathrm{k}} / \mathrm{U}_{\mathrm{x}}^{\mathrm{k}}\right)=1$

Expression (8) is the standard Bowen-LindahlSamuelson condition for optimal provision of a public good, according to which the good is produced to the point where the sum of the marginal rates of substitution between the public good and the private good across all individuals is equal to the price ratio between these two goods, which in this case is unity.

From (6):

$\mathrm{f}_{\mathrm{l}}-\mathrm{x}^{1}=\mathrm{f}_{\mathrm{k}}-\mathrm{x}^{\mathrm{k}}=\theta$

where, $\theta=-\left[1\left(U_{n}^{1} / U_{x}^{1}\right)+k\left(U^{k}{ }_{n} / U^{k}{ }_{x}\right)\right]$, which is the sum of the marginal rates of substitution between membership size and private good consumption across all existing members. Therefore $\theta$ is the congestion charge that would be required to compensate existing members for the disutility of crowding when one more member is added to the community. Equation 9 is the optimal membership condition, which states that the difference between marginal product and average consumption for each factor owner is equal to the (common) marginal congestion cost that each imposes on the group. Put differently, the contribution to output of the marginal factor owner must exactly cover his consumption of the private good plus the congestion cost associated with his entry into the community.

To interpret this condition, define:

$\mathrm{f}(1, \mathrm{k})=1 \mathrm{f}_{\mathrm{l}}+\mathrm{kf} \mathrm{f}_{\mathrm{k}}+\rho$

where, $\rho$ is site rent, or rent attributable to a fixed factor. If $\mathrm{f}(\mathrm{l}, \mathrm{k})$ shows diminishing returns in 1 and $\mathrm{k}$, then $\rho>0$. From (9):

$f_{1}=x^{1}+\theta$ and $f_{k}=x^{k}+\theta$

Substituting (11) into (10):

$f(1, k)-1 x^{1}-k x^{k}=n \theta+\rho$

But, from the budget constraint in $(3), \mathrm{f}(1, \mathrm{k})-\mathrm{x}^{1}-$ $\mathrm{kx}^{\mathrm{k}}=\mathrm{g}$. Therefore (12) can be rewritten as:

$\mathrm{g}=\mathrm{n} \theta+\rho$
Expression (13) implies that, in general, the optimum community finances expenditure on the public good, g, from two sources, namely, revenue from a congestion charge, $n \theta$, and site rent, $\rho$. If $\mathrm{U}_{\mathrm{n}}^{\mathrm{i}}=0$, then $\theta=0$ and there is no congestion rivalry in the sense of Buchanan (1965). In this case, (12) becomes:

$f(1, k)-1 x^{1}-k x^{k}=g=\rho$

This condition means that the entire cost of the public good is paid out of site rent, and the entire rent is used for this purpose. This result is known as the Henry George theorem, because the latter championed the idea of financing public goods out of a non-distortionary land tax (Atkinson and Stiglitz, 1980).

The Henry George condition in (14) can be used to illustrate the effect of spatial rivalry on optimal community membership. Recall from Expression (9) that $f_{l}=x^{1}$ and $f_{k}=x^{k}$ if $\theta=0$, i.e., in the absence of congestion rivalry, the marginal product of the last factor owner added to the community is equal to perperson consumption of the private good. To see the implications of this condition, substitute $f_{1}$ for $x^{1}$ and $f_{k}$ for $\mathrm{x}^{\mathrm{k}}$ in the budget constraint:

$\mathrm{f}(\mathrm{l}, \mathrm{k})-\mathrm{lf}_{\mathrm{l}}-\mathrm{kf} \mathrm{f}_{\mathrm{k}}=\mathrm{g}$

For illustrative purposes, suppose that $1=\mathrm{k}=\mathrm{n} / 2$, and that $x^{1}=x^{k}$. Then (15) can be rewritten as:

$2[\mathrm{f}(\mathrm{l}, \mathrm{k})-\mathrm{g}] / \mathrm{n}=\mathrm{f}_{\mathrm{l}}+\mathrm{f}_{\mathrm{k}}$.

Because $[f(1, k)-g] / n=x^{1}=x^{k},(16)$ requires that the sum of the marginal product of the last worker entering the community and the marginal product of the last capital owner must equal two times the average per-person private good consumption. If this condition is met, each individual's private good consumption will be maximized for any given level of public good provision. An additional entrant into the community has the beneficial effect of increasing the fiscal residual (the difference between each person's average product and his share of the cost of financing the public good) as long as $\mathrm{g} / \mathrm{h}$ falls more rapidly than $\mathrm{f}(\mathrm{l}, \mathrm{k}) / \mathrm{n}$. However, beyond some membership level, the marginal products of labor and capital become so small that the fiscal residual begins to shrink. Thus, in Fig. 1, the fiscal residual-or average after-tax consumption, $[\mathrm{f}(\mathrm{l}, \mathrm{k})-\mathrm{g}] / \mathrm{n}$ is shown as an inverted U-shaped curve. 


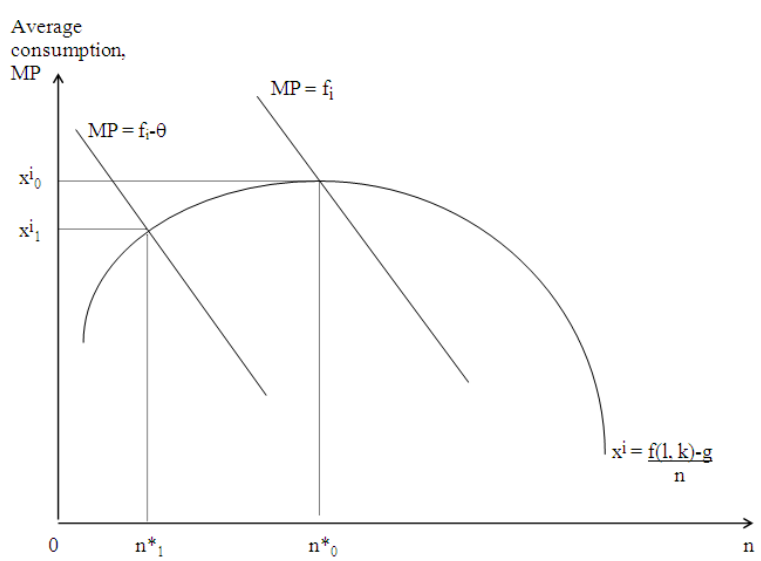

Fig. 1: Local public goods equilibria

The community will continue to add members as long as each additional member contributes more to output than he consumes. The optimal membership size, $n^{*}$, occurs where the marginal member's contribution to output is just equal to average after-tax consumption. This condition, shown in Fig. 1 at $\mathrm{n}_{0}{ }_{0}$, is given by Eq. 15 or 16, which imply that, for each member of the community, marginal product, $\mathrm{f}_{\mathrm{l}}$ or $\mathrm{f}_{\mathrm{k}}$, is equal to average private good consumption, $\mathrm{x}^{\mathrm{l}}$ or $\mathrm{x}^{\mathrm{k}}$, i.e., for any given $\mathrm{g}$, average private good consumption, $[\mathrm{f}(\mathrm{l}, \mathrm{k})-\mathrm{g}] / \mathrm{n}$, is maximized (Atkinson and Stiglitz, 1980; Flatters et al., 1974).

If pure congestion rivalry exists in addition to spatial rivalry, then $\mathrm{U}_{\mathrm{n}}^{\mathrm{i}}<0$ and $\theta>0$. In this case, Eq. 12 holds, and the public good is financed out of a combination of a congestion charge and site rent. It follows from (11) that:

$x^{1}=f_{1}-\theta$ and $x^{k}=f_{k}-\theta$

Optimal membership size no longer maximizes average after-tax consumption, because it is no longer true that $f_{1}=x^{1}$ and $f_{k}=x^{k}$. Instead, optimal membership requires that $\mathrm{x}^{1}$ and $\mathrm{x}^{\mathrm{k}}$ be equated to the true, or "congestion-adjusted," marginal product, which is $\mathrm{f}_{1}$ or $\mathrm{f}_{\mathrm{k}}$ minus congestion costs imposed on the community. Thus, the optimal membership size falls short of that which would maximize average after-tax consumption, due to the effects of pure congestion rivalry. This is shown in Fig. 1 where the parameter $\theta$ shifts the congestion-adjusted marginal product curve of each factor to the left of the actual marginal product and thus ensures that the optimal membership, where the congestion-adjusted marginal product equals average consumption, is less than it would be if there were no congestion and $\theta$ were zero. In Fig. 1 optimal membership falls from $\mathrm{n}_{0}{ }_{0}$ to $\mathrm{n}^{*}$ and average after-tax consumption falls from $\mathrm{x}_{0}^{\mathrm{i}}$ to $\mathrm{x}_{1}^{\mathrm{i}}$ due to the impact of congestion rivalry.

It should be noted that the foregoing analysis is concerned only with the decision of a single club as to the optimal allocation of a local public good and the optimal number of members to share this public good. We have assumed, implicitly, that clubs can be created freely in a way that maximizes utility of club members and no one has to remain outside a club. There are, however, a number of serious existence problems for the optimal club, especially in the context of a global, competitive equilibrium allocation across multiple clubs. First, if the total population to be divided among several clubs is less than the derived efficient club size, then clearly the optimum cannot be attained. More generally, the population must be an exact multiple of the efficient club size in order for a global optimum to exist (Starrett, 1988). This well-known result is due to Pauly (1967; 1970), who showed that the existence of a core, comprising a globally optimal partitioning of the population among a collection of clubs or communities, requires that the quotient of the population divided by the locally optimal membership size must be an integer. See also Cornes and Sandler (1986). Second, there might not be enough clubs to satisfy the preferences of all heterogeneous individuals. A necessary condition for existence of equilibrium is that the number of potential communities must be sufficiently large so that all individuals can locate a public good and tax package ideally suited to their tastes (Cornes and Sandler, 1986). As Scully (1991) points out, spatial convergence of factor prices and income distributions can lead to convergence of public expenditures and taxes across communities, which attenuates opportunities for efficiency-enhancing Tiebout-type migration. Third, non-convexities inherent to the provision of public goods to individuals may preclude the existence of a local public good equilibrium (Atkinson and Stiglitz, 1980). These difficulties are mentioned here as potential caveats, although we do not address them further.

Several implications flow from the model described here, and especially from the optimal membership condition as expressed in Eq. 9, 12, 15 and 17. One of these implications is that owners of either factor of production will prefer to live in a community that contains more, rather than fewer, individuals who own the other factor of production. Thus, for example, workers gain if the optimal sized community comprises primarily capital owners, because the presence of these capital owners, while helping to reduce the per-person share of the financing cost of the local public good, at the same time does not diminish the marginal product 
of labor and even potentially raises it if capital and labor are complements in production. The optimal club is a "Berglas-group," the membership composition of which is heterogeneous due to factor combinations in the production of the private good (Berglas, 1976; McGuire, 1991). From Eq. 15 or 16, it can be seen that for any $\mathrm{g}$, and for any given average level of per-person private good consumption, the lower is the marginal product of capital, the higher must be the marginal product of labor. Conversely, capital owners will prefer to employ their capital in a community with a large number of workers relative to capital owners. Adding more workers reduces the financing burden of the local public good falling on each capital owner without depressing the rate of return to capital.

A further implication of the model, and one more relevant to our present purposes, is that residents of a community will seek to ensure that its size is as close as possible to the optimum, thereby maximizing perperson private good consumption for any given level of g. Eq. 13 implies that the larger the quantity of the public good, g, provided by the community, the greater is the benefit from having a larger number of members. The public good is financed out of a congestion charge and site rent. Revenue from the congestion charge increases as $\mathrm{n}$ increases, not only due to the increase in the number of members paying the congestion fee, but also due to the rise in the optimal value of the fee-permember as a consequence of increasing marginal disutility of additional members, i.e., $\theta$ rises as $n$ increases. Moreover, as $\mathrm{n}$ increases, site rent $\rho$ also rises due to diminishing returns to 1 and $\mathrm{k}$, as can be seen from Eq. 10. Additional members of either type (workers or capital owners) help to reduce the perperson financing burden of the public good by contributing to increased site rent and by augmenting the revenue produced by the congestion charge which further helps to pay for the public good. Hence, for both of these reasons, the larger is $\mathrm{g}$, the greater is the optimal club membership (this result can be obtained easily from the classic Buchanan (1965) club model). One way to interpret this result is that communities whose ongoing expenditures on public goods are high will welcome a larger number of members than communities with low public good expenditures. Not only do the high-expenditure communities need more members to lower per-member financing costs, but they can accommodate these new members without congestion becoming too onerous because they are simultaneously adding to their stocks of public goods. The model does not allow for the possibility of nonlocation specific sources of income. Such income, when brought into a community by new entrants, further reduces each individual's cost of financing local public good supply (Mueller, 1989).

Furthermore, from Eq. 17, the greater is the disutility to an individual club member caused by an increment in membership size, i.e., the more negative is $\mathrm{U}_{\mathrm{n}}^{\mathrm{i}}$ and the greater is $\theta$, the smaller is the optimal size of the community. As shown in Fig. 1, a higher value of the parameter $\theta$ shifts the congestion-adjusted marginal products of both factors further to the left of the unadjusted marginal products and thus ensures that the optimality condition in Eq. 17 produces a lower level of $\mathrm{n}^{*}$. Therefore, the larger is the representative worker's or capital owner's disutility from additional members, the larger is the optimal congestion charge and the smaller is the optimal community membership. The greater the perception of congestion by existing community members, the more strongly they will resist further expansion of membership. This result could be interpreted to mean that communities that already have sunk considerable resources into providing public amenities will incur a larger amount of disutility from sharing those amenities with additional entrants than communities with smaller endowments of shared facilities. Residents of communities that are well endowed with parks, museums, libraries and art galleries are likely to derive greater disutility from congestion than residents of communities sparsely endowed with such facilities. In the limit, a community with zero local public goods will experience zero congestion rivalry.

Taken together, Eq. 9, 12, 15 and 17 imply that optimal membership size and composition of a community are determined at the margin by the disutility caused by congestion rivalry and spatial crowding associated with consumption of a local public good, relative to the marginal net benefits of adding new members of differing types. In general, the entry of one more member into a community helps to finance local public goods by increasing the rent to fixed factors and also raises the marginal products of complementary factors, but the marginal products of substitute factors are reduced and congestion of local public goods is exacerbated. The optimal membership condition trades off all of these effects at the margin and illustrates what McGuire (1991) calls a crucial tension governing group composition, namely, that between "the disadvantage dissimilar people find from cooperating in collective consumption versus the advantage they find from cooperating in production". In our model, the disadvantage from cooperative consumption stems from congestion of local public goods, while the advantage from cooperation in production involves sharing the cost of providing local 
public goods as well as complementarities in production of private goods.

The model described above is an intra-club equilibrium model. It is intended to characterize the essential elements of a local public good optimum, in which each club member's utility is maximized. But changes in the composition and size of the population at large will periodically disturb this club equilibrium, causing changes in factor prices, in optimal membership sizes of individual clubs, and in the number of clubs into which the population is ideally partitioned. Consequently, there must exist certain mechanisms available to communities by which they can regulate their membership sizes and the composition of their memberships. Some of the most obvious of these mechanisms include zoning laws, restrictions on residential or commercial development, anti-growth or pro-growth policies, etc. "Oates (1977) emphasizes the role of local zoning ordinances in regulating the quality of local public goods, most notably education and police protection. But, as noted above, Oates's explanation of optimal community composition is fundamentally different from that offered here, because Oates's analysis is based on complementarities between individuals with different personal characteristics in production of public goods, not on factor complementarities in production of private goods". Our analysis suggests that local growth-promoting measures are more likely in communities with high levels of current expenditure on public amenities, where additional taxpayers are needed to defray financing costs, and less likely in communities whose large existing stocks of public goods make them more susceptible to congestion. Below we test these hypotheses in the case of California cities.

\section{MATERIALS AND METHODS}

The data used here are derived from extensive surveys of California city governments' local growthpromoting policies, supplied to us directly by the authors of the surveys, as well as from the US Population Census. Details of the surveys of California cities' policies are provided in Glickfeld et al. (1996) and Glickfeld and Levine (1992). While some of the pro-growth policies tallied by Glickfeld and Levine (1992) might have been intended to foster higher levels of per capita income in the affected communities rather than regulate membership size per se, most of these policies would have had, at least as a by-product, a positive effect on population growth or density.

We use cross-section regression analysis to test the relationships between the stock of public goods, expenditure on public goods, and the extent of progrowth policies and legislation in California cities. The following variables are used in two regression models, one using a probit estimation technique and the other using logit. Data are from the Glickfeld and Levine (1992) surveys mentioned above unless noted as being US Census data.

\section{Dependent variable:}

PROGROW = Measure of legislation and policies promoting development. PROGROW measures the prevalence of nine different categories of pro-growth policies. The categories are: Higher density rezoning, a fast track process, financial incentives, low development fees, direct infrastructure subsidies, redevelopment incentives, a general growth plan, economic development, as well as "other". This variable, as well as the others described here, are explained in more detail in documentation provided to the authors by Glickfeld et al. (1996). Feel free to contact the authors with any inquiries. Each policy is measured on a scale of 1-5 in terms of its importance or effectiveness in promoting growth for that city. The 1-5 scale used is:

$1=$ Not at all important

$2=$ Not very important

$3=$ Neutral

$4=$ Quite important

$5=$ Very important

The value of PROGROW equals one if, for a city, at least four of the nine categories have a value of 4 or 5. Otherwise PROGROW equals zero.

\section{Independent variables:}

MINORITY = Percentage of each city's population comprising ethnic or racial minorities (United States Census Bureau, 1990)

SENIORS $=$ Percentage of each city's population comprising individuals who are 65 years old or older (United States Census Bureau, 1990)

CENTER $=$ Distance from each city to the nearest major population center, in miles

EXPENDITURE $=$ Real fixed capital expenditures per capita for each city, in 1992, in 1984 dollars (a measure of current expenditure on local public goods) 
STOCK $=$ The sum of real fixed capital expenditures per capita for 1972, 1982 and 1992 for each city, in 1984 dollars (a measure of the existing stock of local public goods). (Since STOCK contains dollar values from different time periods, both EXPENDITURE and STOCK are adjusted for inflation using the urban Consumer Price Index. Values for the urban CPI are from www.economagic.com)

INCOME $=$ Real median household income for each city, in 1990, in thousands of 1984 dollars

Our inclusion of demographic and income variables in the regression analysis is motivated by the necessity to control for factors, other than local public goods attributes, that may reasonably be expected to affect a city's propensity to promote growth. Thus, for example, MINORITY is included on the grounds that some local policies regulating outsiders' access to a community might be determined in part by existing residents' attitudes toward racial or ethnic minorities (Halcoussis and Lowenberg, 1998). SENIORS reflects the possible interest of older residents in restricting entry of younger families whose demands for schooling and other social services might place a fiscal strain on the city. CENTER captures the possibility of congestion spillovers from large urban communities to adjacent regions. INCOME is included as a control for possible wealth effects.

Table 1 presents descriptive statistics for these variables, for 323 cities in California. These are the cities included in the Glickfeld and Levine (1992) dataset for which there are no missing values in the variables listed above. As indicated in Table 1, MINORITY has a large range of 3 to 100. Belvedere, a town consisting of two islands close to San Francisco, has the 3\%, while Compton, an autonomous city within the Los Angeles area, has the highest value, rounding off to $100 \%$. The low for SENIORS is $2 \%$, due to Huron, a small city in Fresno County. Huron had around 6,300 residents as of 1999 (United States Census Bureau, 2000).

Table 1: Descriptive statistics

\begin{tabular}{lrrrr}
\hline Variable & \multicolumn{1}{c}{ Mean } & \multicolumn{1}{c}{ SD } & Minimum & Maximum \\
\hline PROGROW & 0.43 & 0.50 & 0.00 & 1.0 \\
MINORITY & 38.80 & 2.02 & 3.00 & 100.0 \\
SENIORS & 11.98 & 5.67 & 2.00 & 48.0 \\
CENTER & 59.46 & 37.50 & 1.00 & 263.0 \\
INCOME & 28.74 & 14.09 & 11.45 & 114.8 \\
EXPENDITURE & 103.34 & 352.15 & 0.06 & $6,091.0$ \\
STOCK & 252.24 & 1199.78 & 6.00 & $21,459.0$ \\
$\mathrm{~N}$ & 323 & & & \\
\hline
\end{tabular}

The high for SENIORS is $48 \%$, courtesy of Yountville, which is part of Napa Valley and is about half the size of Huron (2,916 residents, as of 1999) (United States Census Bureau, 2000). California's poorest city, measured by median household income in 1990, is Dorris, with $\$ 11,450$. Dorris is a small town of less than 1,000 inhabitants located in the northernmost part of California. The wealthiest city is Rolling Hills, "a private, gated community located atop the scenic hills of the Palos Verdes Peninsula" (http://www.palosverdes.com/rh) in southern California.

EXPENDITURE has a wide range of 0.06 to 6,091 . The low of 0.06 comes from Danville, a suburb of San Francisco that is known for its restrictive growth policies. The high of 6,091 comes from Vernon, an industrial town in Los Angeles County whose slogan is "Exclusively Industrial". Most of the land area in Vernon is used for factories and warehouses, and the 2000 US Population Census puts the population at 91 (http://en.wikipedia.org/wiki/Vernon\%2C_CA). Recall that the EXPENDITURE variable captures a snapshot of the expenditure flow on local public goods at one point in time, in 1992. STOCK also has a wide range, from 6 to 21,459. The 6 belongs to McFarland, in Kern County, an agricultural community. The 21,459 was generated by Vernon.

\section{RESULTS}

Probit and logit regression models are used to test the relationship between, on one side, a city's stock of local public goods and current expenditure on local public goods and, on the other side, local growthpromoting policies. Table 2 reports the results.

Table 2: Logit and probit cross-section results by city (dependent variable is PROGROW)

\begin{tabular}{lcc}
\hline Variable & $\begin{array}{c}\text { Logit coefficients } \\
\text { (t-stats) }\end{array}$ & $\begin{array}{c}\text { Probit coefficients } \\
\text { (t-stats) }\end{array}$ \\
\hline Constant & 1.0800 & 0.07000 \\
MINORITY & $(0.1400)$ & $(0.15000)$ \\
& 0.0100 & 0.06400 \\
SENIORS & $(1.6700)^{\dagger}$ & $(1.69000)^{\dagger}$ \\
& -0.0330 & -0.02100 \\
CENTER & $(-1.2700)$ & $(-1.30000)$ \\
& 0.0040 & 0.00260 \\
INCOME & $(1.6400)$ & $(1.66000)^{\dagger}$ \\
& -0.0230 & -0.01400 \\
EXPENDITURE & $(-1.740)^{\dagger}$ & $(-1.82000)^{\dagger}$ \\
& 0.0430 & 0.00270 \\
STOCK & $(2.5100)^{*}$ & $(2.53000)^{*}$ \\
& -0.0014 & -0.00086 \\
McFadden R & $(-2.4900)^{*}$ & $(-2.57000)^{*}$ \\
$\mathrm{~N}$ & 0.070 & 0.07000 \\
Numbers in parentheses are t-statistics; ${ }^{\dagger}:$ Significant at a $10 \%$ error \\
level; ${ }^{\dagger}$ : Significant at a 5\% error level
\end{tabular}


The coefficient estimates for SENIORS are statistically insignificant in both regression equations. This finding is consistent with Richer (1995), who focuses on anti-growth legislation and confirms that the presence of older residents living in a given locality does not affect support for pro-growth or anti-growth legislation. MINORITY has statistically significant coefficient estimates in both regressions, at a $10 \%$ error level. The coefficient estimates are positive, suggesting that cities with a larger percentage of minority inhabitants display a stronger preference for pro-growth policies, ceteris paribus.

The coefficient estimates for CENTER are positive, but statistically significant only in the probit regression, at a $10 \%$ error level. The coefficient just misses being significant at a $10 \%$ error level in the logit regression. The further a city is from a major population center, the more likely the city is to implement progrowth policies. This result might be due to the fact that a greater distance from the nearest large urban center effectively insulates a community from negative spillovers, such as spatial displacement of housing development from more congested areas to less congested neighboring regions. At the same time, cities located closer to urban centers might perceive less need to promote growth because they can free ride on some of the services provided by their larger neighbors.

The coefficient estimates for INCOME are negative and statistically significant at a $10 \%$ error level in both regression equations. This finding indicates that wealthier communities are less interested in promoting development and are perhaps more concerned about congestion, so that pro-growth polices are less popular. Suppose, for example, that two cities are alike in every way except that one has a median household income that is $\$ 10,000$ higher than the other. The -0.014 coefficient estimate for INCOME in the second regression equation means that the wealthier city will have, on average, $14 \%$ less chance than the poorer city of having four or more policies that are ranked "quite important" or "very important" in promoting growth, ceteris paribus. INCOME is measured in thousands of dollars; the coefficient estimate in the second regression equation means that, for each $\$ 1,000$ increase in a city's median household income, there would be $1.4 \%$ less chance of having four or more policies that are ranked "quite important" or "very important" in promoting growth.

The other coefficient estimates in the second regression equation can be interpreted in a similar manner. The first regression is logit, therefore the interpretation of the coefficient estimates is a little different. The -0.023 coefficient estimate for INCOME in the first regression equation means that, for the two cities mentioned above, the relative odds of the wealthier one having four or more policies that are ranked "quite important" or "very important" are $23 \%$ lower than for the poorer one, ceteris paribus. (Note that results of the logit model are properly interpreted as changes in odds $(\mathrm{p} /(1-\mathrm{p}))$ rather than probability $(\mathrm{p})$ as in the probit model. Multiplying a logit coefficient estimate by 100 gives the percentage change in odds for a one unit change in the relevant independent variable (Roncek and Swatt, 2006). Since INCOME is in thousands of dollars, and here the example is for a city that has a median household income $\$ 10,000$ higher than another, the original coefficient, -0.023 , is multiplied by 10 for the difference in median incomes between the cities, and then by 100 to convert it into the percentage change in odds).

Turning to the key independent variables in the model, both EXPENDITURE and STOCK have statistically significant coefficient estimates in both regression equations, at a 5\% error level. The estimated coefficients on EXPENDITURE are positive, consistent with the prediction of our local public goods theory that cities spending more on public goods will want to promote growth in order to increase the number of taxpayers to help finance their expenditures. The 0.043 coefficient estimate in the first regression equation means that a city that spends an additional dollar per capita on local public goods will increase its odds of having four or more policies that are ranked "quite important" or "very important" by $4.3 \%$, ceteris paribus. Now consider the 0.0027 coefficient estimate for EXPENDITURE in the second regression equation. Here, the city that spends $\$ 1$ more per capita on local public goods will have a $0.27 \%$ greater chance of having four or more policies that are ranked "quite important" or "very important" in promoting growth, ceteris paribus. For $\$ 100$ more per capita spent on local public goods, the increase in the probability would be $27 \%$.

The coefficient estimates for STOCK are negative and statistically significant at a 5\% error level. Cities that have a larger stock of local public goods are less likely to implement pro-growth policies. This result confirms our hypothesis that cities with a larger endowment of public goods are likely to be more concerned about limiting congestion than encouraging growth. The estimated coefficient of -0.0014 for STOCK in the first regression equation means that a city that has a stock of local public goods that is larger by $\$ 100$ per capita than a similar city would lower its odds of having four or more policies that are ranked "quite important" or "very important" by $14 \%$, ceteris 
paribus. In the second regression equation, the estimated coefficient of -0.00086 for STOCK means that the city with $\$ 100$ more local public goods per capita would have an $8.6 \%$ lower probability of having four or more policies that are ranked "quite important" or "very important" in promoting growth, ceteris paribus.

\section{DISCUSSION}

A theory of local public goods allocation, characterized by both pure congestion rivalry and spatial rivalry in consumption, is used to explain the determination of optimal jurisdiction size. According to this theory, the optimal number of community members is that which, for any given quantity of the local public good supplied, equates the marginal product of the last member, net of congestion costs, to average after-tax private good consumption. The addition of new residents benefits existing members of the community by reducing the per-person share of the cost of financing the local public good, but also causes congestion of public amenities. Each jurisdiction must trade off these two effects at the margin to determine optimal membership size. Furthermore, a community must have some method of regulating its size to ensure that the number of residents does not deviate too far from the optimum.

Local growth-management policies, such as municipal zoning laws and pro-growth measures, are used by jurisdictions to regulate entry of new residents. The local public goods theory predicts that communities with high levels of current expenditure on local public goods will, in general, seek to attract new residents to help finance these expenditures. Such communities will have less to fear from congestion than their counterparts with lower expenditure levels, since they are augmenting their stocks of public goods at the same time that they are adding members. On the other hand, communities with large endowments of local public goods already in place will be less interested in expanding membership due to concerns about congestion of their existing facilities. These hypotheses are tested with survey data on pro-growth policies enacted by California cities in the 1980s. The results support the main hypotheses of the local public goods theory. Cities with high levels of expenditure on local public goods typically had more effective pro-growth policies in force. At the same time, cities with large existing stocks of local public goods are found to have less effective pro-growth measures. We also find that cities with larger minority populations and cities located relatively far away from major population centers were more likely to adopt policies conducive to growth.

\section{CONCLUSION}

Our findings suggest that changes in stocks and flows of public goods are useful predictors of which jurisdictions can be expected to implement growth controls or pro-growth policies. Such predictions may be helpful to analysts of real estate markets as well as to policy analysts interested in forecasting fiscal revenues likely to be generated within specific regions.

\section{ACKNOWLEDGMENT}

"The authors thank Madelyn Glickfeld and Ned Levine for the use of their data." This addition is mandatory, as Madelyn Glickfeld and Ned Levine specifically required us to acknowledge their provision of the data as a condition for our use of these data.

Also, at the end of the "Corresponding Author" footnote as it currently appears, there is a redundant " 1 " after the Fax number.

\section{REFERENCES}

Atkinson, A.B. and J.E. Stiglitz, 1980. Lectures on Public Economics. McGraw-Hill, New York, ISBN: 10: 0070841055, pp: 619.

Berglas, E., 1976. Distribution of tastes and skills and the provision of local public goods. J. Public Econ., 6: 409-423.

http://ideas.repec.org/a/eee/pubeco/v6y1976i4p409 $-423 . \mathrm{html}$

Brueckner J.K., 1998. Testing for strategic interaction among local governments: The case of growth controls. J. Urban Econ., 44: 438-467. http://ideas.repec.org/a/eee/juecon/v44y1998i3p43 8-467.html

Buchanan, J.M., 1965. An economic theory of clubs. Economica, 32: 1-14. http://www.jstor.org/pss/2552442

Buchanan, J.M. and C.J. Goetz, 1972. Efficiency limits of fiscal mobility: An assessment of the Tiebout model. J. Public Econ., 1: 25-43. http://ideas.repec.org/a/eee/pubeco/v1y1972i1p2543.html

Buchanan, J.M. and R.E. Wagner, 1970. An Efficiency Basis for Federal Fiscal Equalization. In: The Analysis of Public Output, Margolis, J. (Ed.). Columbia University Press, New York, pp: 139-158. 
Byun, P., B.S. Waldorf and A.X. Esparza, 2005. Spillovers and local growth controls: An alternative perspective on suburbanization. Growth and Change, 36: 196-219. DOI: 10.1111/j.14682257.2005.00274.x

Cornes, R. and T. Sandler, 1986. The Theory of Externalities, Public Goods, and Club Goods. 2nd Edn., Cambridge University Press, Cambridge, ISBN: 10: 0521477182, pp: 616.

Fennell, L.A., 2001. Beyond exit and voice: User participation in the production of local public goods. Public Law Research Paper No. 31, University of Texas Law, Austin, TX. http://papers.ssrn.com/sol3/papers.cfm?abstract_id $=288807$

Fennell, L.A., 2004. Contracting communities. Univ. Illinois Law Rev., 4: 829-98. http://lawreview.law.uiuc.edu/publications/2000s/2 004/2004_4/Fennell.pdf

Flatters, F., V. Henderson and P. Mieszkowski, 1974. Public goods, efficiency, and regional fiscal equalization. J. Pub. Econ., 3: 99-112. http://ideas.repec.org/a/eee/pubeco/v3y1974i2p99112.html

Garcia, D., 2004. Urban growth controls under competition and fiscal revenues, 2004. Urban Public Econ. Rev., 1: 13-36. http://dialnet.unirioja.es/servlet/articulo?codigo $=14$ 54485

Glickfeld, M. and N. Levine, 1992. Regional Growth...Local Reaction: The Enactment and Effects of Local Growth Control and Management Measures in California. Lincoln Institute of Land Policy, Cambridge, MA., ISBN: 9781558441194, pp: 164.

Glickfeld, M., N. Levine and W. Fulton, 1996. Home rule: Local growth control...regional consequences. Metropolitan Water District of Southern California and the Southern California Association of Governments, Los Angeles.

Halcoussis, D. and A.D. Lowenberg, 1998. Local public goods and Jim Crow. J. Inst. Theor. Econ., 154: 599-621.

http://ideas.repec.org/a/mhr/jinste/urnsici09324569(199812)1544_5991pgajc_2.0.tx_2-t.html

Levine, N., 1999. The effects of local growth controls on regional housing production and population redistribution in California. Urban Stud., 36: 2047-2068. DOI: $10.1080 / 0042098992539$

McGuire, M.C., 1991. Group composition, collective consumption, and collaborative production. Am. Econ. $\quad$ Rev., 81: 1391-1407. http://ideas.repec.org/a/aea/aecrev/v81y1991i5p13 91-407.html
Mueller, D.C., 1989. Public Choice II. Cambridge University Press, Cambridge, ISBN: 0521370833, pp: 518.

Oates, W.E., 1977. The Use of Local Zoning Ordinances to Regulate Population Flows and the Quality of Local Services. In: Essays in Labor Market Analysis, Ashenfelter, O.C. and W.E. Oates (Eds.). John Wiley and Sons, New York, ISBN: 0470992220, pp: 201-219.

Pauly, M.V., 1967. Clubs, commonality, and the core: An integration of game theory and the theory of public goods. Economica, 34: 314-324. http://www.jstor.org/pss/2552030

Pauly, M.V., 1970. Cores and clubs. Public Choice, 9: 53-65. http://www.jstor.org/pss/30022622

Richer, J., 1995. Explaining the vote for slow growth. Public Choice, 82: 207-223. http://ideas.repec.org/a/kap/pubcho/v82y1995i34p207-23.html

Roncek, D.W. and M.L. Swatt, 2006. For those who like odds: A direct interpretation of the logit coefficient for continuous variables. Soc. Sci. Q., 87: 731-738.

http://cat.inist.fr/?aModele $=$ afficheN\&cpsidt $=1812$ 0696

Schwab, R.M. and W.E. Oates, 1991. Community composition and the provision of local public goods: A normative analysis. J. Public Econ., 44: 217-237.

http://ideas.repec.org/a/eee/pubeco/v44y1991i2p21 7-237.html

Scully, G.W., 1991. The convergence of fiscal regimes and the decline of the Tiebout effect. Public Choice, 72: 51-59.

http://ideas.repec.org/a/kap/pubcho/v72y1991i1p51 $-59 . \mathrm{html}$

Starrett, D.A., 1988. Foundations of Public Economics, Cambridge University Press, Cambridge, ISBN: 0521348013, pp: 315.

Tiebout, C.M., 1956. A pure theory of local expenditures. J. Politic. Econ., 64: 416-424. http://ideas.repec.org/a/ucp/jpolec/v64y1956p416.h tml

United States Census Bureau, 1990. Statistical abstracts.

http://www.census.gov/prod/www/abs/statab.html

United States Census Bureau, 2000. Statistical abstracts.

http://www.census.gov/prod/www/abs/statab.html 